ORIGINAL ARTICLE

\title{
FRG2, an FSHD candidate gene, is transcriptionally upregulated in differentiating primary myoblast cultures of FSHD patients
}

\author{
T Rijkers*, G Deidda*, S van Koningsbruggen, M van Geel, R J L F Lemmers, J C T van Deutekom, \\ D Figlewicz, J E Hewitt, G W Padberg, R R Frants, S M van der Maarel
}

J Med Genet 2004;41:826-836. doi: 10.1136/jmg.2004.019364

*Both authors contributed equally to this work

See end of article for authors' affiliations

.....................

Correspondence to: Dr S M van der Maarel, Department of Human Genetics, Center for Human and Clinical Genetics, Leiden University Medical Center,

Wassenaarseweg 72

2333 AL Leiden, The

Netherlands; maarel@ lumc.nl

Revised version received 18 June 2004

Accepted for publication 20 June 2004
Background: Autosomal dominant facioscapulohumeral muscular dystrophy (FSHD) is associated with partial deletion of the subtelomeric D4Z4 repeat array on chromosome 4qter. This chromosomal rearrangement may result in regional chromatin relaxation and transcriptional deregulation of genes nearby.

Methods and results: Here we describe the isolation and characterisation of FRG2, a member of a chromosomally dispersed gene family, mapping only $37 \mathrm{~kb}$ proximal to the D4Z4 repeat array. Homology and motif searches yielded no clues to the function of the predicted protein. FRG2 expression is undetectable in all tissues tested except for differentiating myoblasts of FSHD patients, which display low, yet distinct levels of FRG2 expression, partly from chromosome 4 but predominantly originating from its homologue on chromosome 10. However, in non-FSHD myopathy patients only distantly related FRG2 homologues are transcribed, while differentiating myoblasts from healthy controls fail to express any member of this gene family. Moreover, fibroblasts of FSHD patients and control individuals undergoing forced Ad5-MyoD mediated myogenesis show expression of FRG2 mainly originating from chromosome 10. Luciferase reporter assays show that the FRG2 promoter region can direct high levels of expression but is inhibited by increasing numbers of D4Z4 repeat units. Transient transfection experiments with FRG2 fusion-protein constructs reveal nuclear localisation and apparently FRG2 overexpression causes a wide range of morphological changes.

Conclusion: The localisation of FRG2 genes close to the D4Z4 repeats on chromosome 4 and 10, their transcriptional upregulation specifically in FSHD myoblast cultures, potential involvement in myogenesis, and promoter properties qualify FRG2 as an attractive candidate for FSHD pathogenesis.
$\mathrm{F}$ acioscapulohumeral muscular dystrophy (FSHD) is the third most common inherited myopathy with an incidence of 1:20 000. Clinically, the disease is foremost characterised by a progressive weakness and atrophy of the facial, shoulder, and upper arm muscles, but extra-muscular symptoms such as retinovasculopathy, mental retardation, and epilepsy are also part of the clinical spectrum. ${ }^{1-3}$ The disease displays an autosomal dominant mode of inheritance and its major locus (FSHDl) was mapped to the subtelomere of the long arm of chromosome $4(4 \mathrm{q} 35)$ by linkage analysis. ${ }^{45}$

Over $95 \%$ of FSHD patients carry a deletion on chromosome $4 \mathrm{q} 35 .^{6}$ This subtelomere is mainly composed of a tandem repeat array consisting of $3.3 \mathrm{~kb}$ units (D4Z4). In the population, the D4Z4 repeat array is polymorphic and may contain between 11 and 150 units. Due to the deletion of an integral number of these repeated D4Z4 elements, the majority of patients with FSHD carry only 1 to 11 units..$^{7-9}$ In general, an inverse relationship has been established between the residual repeat size and the severity and age at onset of the disease. ${ }^{10} 11$

It has been proposed that FSHD may be explained by a position effect variegation model, ${ }^{8}{ }^{12}$ or by a differential long distance cis looping model. ${ }^{13}$ In those models the contraction of the D4Z4 repeat leads to the transcriptional upregulation of 4qter genes by a spreading or looping mechanism originating from D4Z4. In another model, Winokur et al ${ }^{14}$ proposed that alterations in nuclear positioning of chromosomes may lead to general gene deregulation, resulting in a defect in myogenic differentiation in FSHD. Both an increased frequency of interaction between chromosomes $4 \mathrm{q}$ and $10 \mathrm{q}$ in FSHD patients, ${ }^{15}$ as well as an increased frequency of translocated chromosome 4-type repeats on chromosome 10 in individuals that are mosaic for the D4Z4 rearrangement have been observed, ${ }^{16}$ suggesting that exchanges and crosstalk between these chromosomes is part of FSHD pathogenesis, although the majority of rearrangements seem to occur intrachromosomally. ${ }^{17}$ Nevertheless, all these effects may involve partial demethylation of the D4Z4 repeat array upon deletion of D4Z4 units. ${ }^{18}$ Additional evidence shows that a repressor complex can bind to D4Z4, thus regulating expression of genes in or near D4Z4. ${ }^{19}$

Another interesting feature of the D4Z4 repeated element itself is the presence of an open reading frame (ORF) encoding a putative double homeobox sequence. ${ }^{8912}{ }^{20}$ This ORF, DUX4, is preceded by a putative promoter element that displays high transcriptional activity in transient expression studies ${ }^{20}$ suggestive for a pathogenic transcriptional role of the D4Z4 element in FSHD. Nevertheless, in vitro and in vivo, expression of DUX4 has never been demonstrated in FSHD. ${ }^{21}$ Moreover, the presence of a highly similar repeat structure on

Abbreviations: DSM, desmin storage myopathy; EGFP, enhanced green fluorescent protein; FISH, fluorescence in situ hybridisation; FSHD, facioscapulohumeral muscular dystrophy; HS, horse serum; NLS, nuclear localisation signals; ORF, open reading frame; PROMM, proximal myotonic myopathy; VSV-G, vesicular stomatitis virus glycoprotein 
chromosome $10^{22}{ }^{23}$ that may vary in length between 1 and $>150$ units without pathological consequences renders a direct involvement of DUX4 questionable. In addition, in approximately $20 \%$ of the Dutch population, chromosome 4 type repeat arrays have been identified on chromosome 10, or vice versa. ${ }^{24}{ }^{25}$ In contrast, short (partial) D4Z4 repeat arrays on chromosome 10 have never been reported in FSHD. ${ }^{26}$

At $80 \mathrm{~kb}$ proximal to the $\mathrm{D} 4 \mathrm{Z} 4$ repeat array, a member of the $\beta$-tubulin subfamily (TUBB4Q) has been identified. The high allelic sequence variability of TUBB4Q and the lack of expression of this gene suggest it may be a pseudogene. ${ }^{28}$ In the past, another candidate gene for FSHD was identified at $120 \mathrm{~kb}$ proximal to D4Z4: FRG1 (FSHD Region Gene 1). This gene is ubiquitously transcribed and encodes a protein that seems to be involved in RNA processing. ${ }^{29}$ It is highly conserved between vertebrates and non-vertebrates. ${ }^{30}$ However, analysis of FRG1 expression levels in muscle biopsies of FSHD patients yields controversial results ${ }^{13} 141931$ (also own observations).

Here, we characterise a novel gene, FSHD Region Gene $\underline{2}$ $(F R G 2)$, which maps only $37 \mathrm{~kb}$ proximal to the D4Z4 repeat array. In contrast to data presented by Gabellini et al, ${ }^{19}$ FRG2 expression was very low to undetectable both in control and FSHD muscle using quantitative real time RT-PCR. However, we demonstrate that FRG2 is upregulated in differentiating myoblast cultures of FSHD patients compared to healthy controls. Its expression in $M y o D$ driven myogenesis in fibroblasts indicates that FRG2 may play a role in the myogenic process. In addition, transient transfection experiments suggest that increasing numbers of D4Z4 units inhibit expression of FRG2. These results render FRG2 an attractive candidate gene contributing to FSHD pathogenesis.

\section{METHODS}

\section{Gene identification, characterisation, and genomic} distribution

The sequence of PAC clone 226K22 (GenBank accession no. AF146191) was used for the in silico gene prediction by the Genotator browser. ${ }^{32}$ A region of $3 \mathrm{~kb}$ just distal of D4S2463 containing four predicted exons preceded by a putative muscle specific promoter was termed FRG2 (FSHD Region Gene 2). The structure of FRG2 was initially characterised by RT-PCR on RNA of the monochromosomal rodent somatic cell hybrid GMI 1687 containing human chromosome 4 as its only human component (Coriell Cell Repositories, Camden, NJ, USA). GM11687 constitutively expresses FRG2. The primers used for RT-PCR are shown in fig 1 and are available upon request. The transcription initiation site was determined by 5' RACE, while 3' RACE was used to identify the poly-adenylation signals (see under "RT-PCR"). The sequence of the chromosome 10 homologue was obtained from cosmid 23D1l (acc. no. AF035179).

DNA from a monochromosomal somatic cell hybrid panel (UK HGMP Resource Center, Cambridge, UK) was used to determine the chromosomal origin of FRG2 related sequences by PCR using the primers $2 \mathrm{f}$ and $3 \mathrm{r}$. To analyse the polymorphisms between the chromosome 4 and 10 copy of $F R G 2$, genomic DNA from the monochromosomal cell lines GMl1687, 4L10 (gift from E Stanbridge, Irvine, CA), HHW416 (gift from M Altherr, Los Alamos, NM), SU10 (gift from S Winokur, Irvine, CA), and PAC clone RCPI-1-226K22 (all chromosome 4), cell lines 726-8a (UK HGMP Resource Center) and GMI1688 (HAl0) (Coriell Cell Repositories), PAC RCPI-1-170K23, and cosmid 23D11 (all chromosome 10) was amplified using the primers $4 \mathrm{f} 3$ and $4 \mathrm{r} 2$, and the PCR product was sequenced and compared.

\section{Myoblast culture}

Myoblasts were isolated from two healthy males and one healthy female (myo 1, myo 5, and myo 7, respectively), three confirmed male FSHD patients (myo 2 carrying an allele of eight D4Z4 units, and myo 4 and myo 8 both carrying an allele of three D4Z4 units), a proximal myotonic myopathy (PROMM) patient, and a desmin storage myopathy (DSM) patient. The site of biopsy was quadriceps, except for myo 4, which was derived from the biceps. Myoblasts were isolated essentially as described ${ }^{33}$ and cultured in SKGM medium (Cambrex Bio Science, Walkersville, MD, USA) supplemented with $20 \%$ FBS according to the manufacturer's instructions. Myoblasts of p. 6-10 were grown to $70 \%$ confluency and differentiation was initiated by changing to DMEM, high glucose, supplemented with $2 \%$ horse serum (HS; Gibco Invitrogen, Merelbeke, Belgium). Differentiation was prolonged for 2-5 days.

\section{Forced myogenesis}

Dermal fibroblasts of an FSHD patient (91RD215) and a healthy individual (VH10) were cultured in DMEM high glucose, supplemented with $10 \%$ FBS. Fibroblasts were grown to $70 \%$ confluency for infection with Ad5 derived, replication defective adenoviral vector expressing the full length murine $M y o D$ cDNA under the transcriptional control of the Rous sarcoma virus LTR. ${ }^{34}{ }^{35}$ The infection was carried out at a multiplicity of infection of 30 in DMEM/2\% HS.

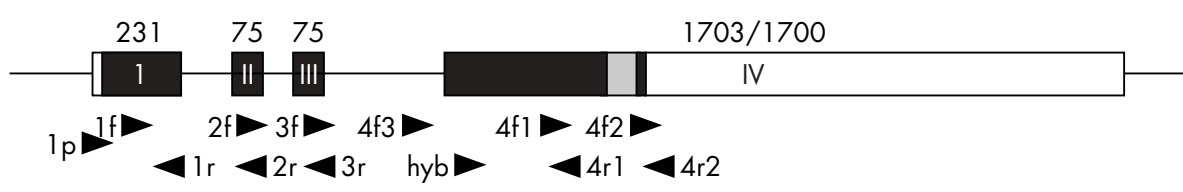

Figure 1 (A) Genomic structure of the FRG2 gene. FRG2 consists of four exons (boxes), and the ORF (black) starts in exon 1 and ends in exon 4 . The LINE sequence in the ORF is in grey. The exon sizes (bp) are depicted above, and the primers used in this study are shown below the exons. (B) Exon sizes and splice sites of FRG2. Intron sequences are in lower case, and exon sequences in capital letters.

B

\begin{tabular}{c|c|c|c|c} 
Exon & $\begin{array}{c}\text { Nucleotide } \\
\text { position }\end{array}$ & $\begin{array}{c}\text { Exon } \\
\text { size }\end{array}$ & $\begin{array}{c}\text { Splice } \\
\text { acceptor site }\end{array}$ & $\begin{array}{c}\text { Splice } \\
\text { donor site }\end{array}$ \\
\hline 1 & 1 & 231 & - & AAGgtaag \\
2 & 232 & 75 & cagagGAT & CAGgtaag \\
3 & 278 & 75 & cagagAAC & CAGgtaga \\
4 & 382 & 1703 & tcttgCAG & - \\
& 385 & 1700 & tgcagGGA & -
\end{tabular}


Following an infection period of $2 \mathrm{~h}$ at $37^{\circ} \mathrm{C}$, the medium was replaced by DMEM $/ 4 \%$ Ultroser-G (Gibco Invitrogen). Myogenic differentiation was initiated after 2 days by changing the Ultroser-G content to $0.4 \%$.

\section{RNA extraction}

Using the Instapure RNA extraction kit (Eurogentec, Seraing, Belgium) according to the manufacturer's instructions, total RNA was extracted from four monochromosomal cell hybrids: GM11687, 4L10, and GM11688 (carry D4Z4 repeat arrays of 140, 85, and $60 \mathrm{~kb}$, respectively), and 762-8a (mosaic for repeat arrays of 150 and $120 \mathrm{~kb}$ ). Similarly, RNA was extracted from the Ad5-MyoD infected fibroblasts during proliferation, 2 days after infection (before differentiation) and at 2, 4, and 6 days after induction of differentiation. RNA extraction from myoblast cultures (p. 6-10) was done during proliferation, and after 1, 3, and 5 days of differentiation.

\section{RT-PCR}

In order to clone the $F R G 2$ transcript, randomly primed first strand cDNA synthesis was performed using Superscript II (Invitrogen, Carlsbad, CA, USA). The transcription initiation site was determined by 5' RACE. After first strand synthesis, cDNA was incubated with TdT (Amersham Pharmacin Biotech, Buckinghamshire, UK) in the presence of $2 \mathrm{mM}$ dATP according to the manufacturer's instructions. Both 5' and $3^{\prime}$ RACE were performed using the primer dT-EXTV in combination with a gene specific primer ( $3 \mathrm{r}$ and $3 \mathrm{f}$, respectively). Subsequently, nested PCR was performed using a gene specific primer ( $1 \mathrm{r}$ or $2 \mathrm{r}$ for $5^{\prime}$ RACE and $4 \mathrm{fl}$ for $3^{\prime}$ RACE) in combination with the primer EXT2. Primers are depicted in fig 1 and all primer sequences are available upon request.

Amplification of FRG2 transcripts for sequence analysis was done in 35 cycles of $40 \mathrm{~s}$ at $94^{\circ} \mathrm{C}, 40 \mathrm{~s}$ at $55^{\circ} \mathrm{C}$, and $90 \mathrm{~s}$ at $72^{\circ} \mathrm{C}$, using primers $1 \mathrm{p}$ and $4 \mathrm{r} 2$. Nested amplifications of 25 cycles were performed using $1 \mu \mathrm{l}$ of the first amplification products and primers $3 \mathrm{f}$ and $4 \mathrm{rl}$.

For radioactive and real time RT-PCR, RNA was treated with RNAse free DNAse I (Promega Benelux, Leiden, The Netherlands) prior to cDNA synthesis. RNA isolated from the monochromosomal cell line GM11687, which expresses $F R G 2$, was used to test all primersets and as a positive control in RT-PCR reactions. To obtain radioactively labelled FRG2 PCR products, initially 40 cycles (reaction volume $25 \mu \mathrm{l}$, primers $3 \mathrm{f}$ and $4 \mathrm{rl}$ ) were performed: $40 \mathrm{~s}$ at $94^{\circ} \mathrm{C}, 40 \mathrm{~s}$ at $55^{\circ} \mathrm{C}$, and $40 \mathrm{~s}$ at $72^{\circ} \mathrm{C}$. Then $12.5 \mu \mathrm{l}$ of this PCR product was amplified for one cycle in the presence of $2.5 \mu \mathrm{Ci} \alpha\left[{ }^{32} \mathrm{P}\right] \mathrm{dCTP}$, adding fresh primers, buffer, and Taq polymerase to a final volume of $25 \mu \mathrm{l}$. GAPDH was amplified similarly in 25 cycles using GAPDHf and GAPDHr primers. The products were separated by $5 \%$ PAGE and detected by autoradiography.

Real time RT-PCR was performed on an ABI-Prism 7700 Sequence Detector, running 40 cycles of $15 \mathrm{~s}$ at $95^{\circ} \mathrm{C}, 60 \mathrm{~s}$ at $60^{\circ} \mathrm{C}$ (initial denaturation $10 \mathrm{~min}$ at $95^{\circ} \mathrm{C}$ ), using SYBR Green PCR Master Mix (Applied Biosystems, Foster City, CA, USA). Primersets spanning an intron (sequences available upon request) were designed using Primer Express 1.0 and results were analysed and quantified using SDS 1.9.1 software (Applied Biosystems).

\section{Sequence analysis}

PCR products were either cloned in the PCR2.1-TOPO cloning vector (Invitrogen) and sequenced using the M13 forward and reverse vector primers, or directly purified using the PCR purification kit (Qiagen, Hilden, Germany) and sequenced using gene specific primers. Sequence reactions were performed with the BigDye Terminator cycle sequencing kit
(Applied Biosystems) and analysed on an ABI377 DNA sequencer.

\section{Expression vector constructs and transfection}

The full length FRG2 cDNA was cloned in frame in pSUPERCATCH, ${ }^{36}$ pSG8, ${ }^{37}$ and pEGFP-Cl (Clontech, Palo Alto, CA, USA). These vectors fuse the FRG2 protein to different aminoterminal tags: FLAG, vesicular stomatitis virus glycoprotein (VSV-G), and enhanced green fluorescent protein (EGFP), respectively.

Then $20 \mathrm{~h}$ prior to transfection, $2 \times 10^{4}$ COS-1, U2OS human osteosarcoma cells, TE671 human rhabdomyosarcoma cells (gift from Dr A Belajew, Mons, Belgium), or human myoblasts were plated on coverslips in 24-well tissue culture plates. Cells were transiently transfected with Fugene (Roche, Basel, Switzerland) according to the manufacturer's instructions. Briefly, $1 \mu \mathrm{l}$ Fugene was mixed with $20 \mu \mathrm{l}$ DMEM and left for $5 \mathrm{~min}$ at room temperature. Subsequently, $0.2 \mu \mathrm{g}$ Qiagen purified plasmid DNA was added and incubated for $15 \mathrm{~min}$ at room temperature. The cells were refreshed with $0.3 \mathrm{ml}$ of medium and the FugeneDNA mix was added dropwise to the medium. COS- 1 and TE671 cells were fixed $24-48 \mathrm{~h}$ after transfection, human myoblasts were allowed to differentiate for 3 days prior to fixation.

\section{Promoter reporter constructs}

To generate luciferase reporter constructs, a $3.4 \mathrm{~kb}$ BglII fragment immediately preceding the ORF of FRG2 was cloned into pGL3-Basic (Promega), both in the forward and the inverted orientation. A smaller construct containing 800 bp including the CAAT and TATA boxes was generated by internal deletion of the BglII-BclI fragment. Next, a $3.3 \mathrm{~kb}$ $K p n I$ D4Z4 repeat fragment was isolated from lambda42 phage DNA (acc. no. AF117653) ${ }^{70}$ and inserted into the KpnI restriction site of pGL3 basic and of the pGL3 vector containing the 3.4 or $0.8 \mathrm{~kb} F R G 2$ promoter fragment, respectively. Constructs in which the D4Z4 unit was inserted in a forward orientation were selected. Further D4Z4 repeat units were then introduced into the constructs carrying FRG2 promoter fragments by inserting (partially digested) SfiI fragments (again isolated from lambda42 phage DNA) into the unique and directional SfiI site of the D4Z4 KpnI unit. This resulted in pGL3 vectors in which no, one, two, or three D4Z4 units were directionally cloned $5^{\prime}$ to the $F R G 2$ promoter driving luciferase expression. A construct carrying one D4Z4 unit but no FRG2 promoter was used as a control for the activity of D4Z4 alone. Transfection in TE67l human rhabsomyosarcoma and in U2OS cells was performed as described under "Expression vector constructs and transfection", but in six-well plates (Greiner Bio-One, Longwood, FL, USA) and with $0.5 \mu \mathrm{g}$ of the reporter construct; efficiency was controlled by co-transfection of $0.5 \mu \mathrm{g}$ pCMVLacZ. For each construct three to six wells per cell type were transfected and analysed independently. Luciferase and $\beta$-galactosidase activity were determined using the appropriate assay systems (Promega). Activity of a construct was expressed as luciferase units per unit of $\beta$-galactosidase and compared to the empty pGL3-Basic vector.

\section{Immunohistochemistry}

Then 24-48 h after transfection, cells cultured on coverslips were washed with PBS and fixed in 2\% paraformaldehyde/ $0.1 \%$ Triton X-100 for $20 \mathrm{~min}$. After washing twice in PBS/ $0.1 \%$ Triton X-100, GFP transfected cells were dehydrated and embedded in Vectashield (Vector Laboratories, Burlingame, CA, USA). Cells transfected with FLAG or VSV fusion constructs were washed twice in PBS/0.1\% Triton X100 , once in $\mathrm{PBS} / 1 \% \mathrm{BSA}$ (fraction V), blocked in $0.1 \mathrm{M}$ 
A

$>1$

1 CA CAC TCT GCC TTT GGA CGT GAG AGA GAG CGC ACC TTT CAC TTG AGC 47

48 TTC AAC ATG GGA AAG GGA AAT GAA GAC TCC GAT CTC CAC TGC TCC TCC 95 $\begin{array}{llllllllllllll}M & G & K & G & N & E & D & S & D & \text { L } & \text { H } & C & S & S\end{array}$

96 ATC CAG TGC TCC ACT GAC CAG CCC CCT TTC CAA CAG ATC TCC TTT ACA 143 $\begin{array}{llllllllllllllll}I & Q & C & S & T & D & Q & P & P & F & Q & Q & I & S & F & T\end{array}$

144 GAA AAG GGC TCA GAT GAG AAG AAA CCA TTC AAA GAA AAA GGC AAG ACC 191 $\begin{array}{llllllllllllllll}\mathrm{E} & \mathrm{K} & \mathrm{G} & \mathrm{S} & \mathrm{D} & \mathrm{E} & \mathrm{K} & \mathrm{K} & \mathrm{P} & \mathrm{F} & \mathrm{K} & \mathrm{E} & \mathrm{K} & \mathrm{G} & \mathrm{K} & \mathrm{T}\end{array}$

192 GCC TTC TCC CAT TCC AGT GAG AAG CAC ATA CAA AGG CAA GGA TCG GAG 239

$\begin{array}{llllllllllllllll}A & F & S & H & S & S & E & K & H & I & Q & R & Q & G & S & E\end{array}$

240 CCC AAT CCA AAC AAG GAG AAT TCT GAG GAA ACC AAG CTC AAG GCC GGG 287 $\begin{array}{llllllllllllllll}\mathrm{P} & \mathrm{N} & \mathrm{P} & \mathrm{N} & \mathrm{K} & \mathrm{E} & \mathrm{N} & \mathrm{S} & \mathrm{E} & \mathrm{E} & \mathrm{T} & \mathrm{K} & \mathrm{L} & \mathrm{K} & \mathrm{A} & \mathrm{G}\end{array}$

$>3$

288 AAC AGC ACT GCT GGA TCA GAA CCA GAG TCC AGC TCA TAT CGG GAA AAC 335 $\begin{array}{llllllllllllllll}\mathrm{N} & \mathrm{S} & \mathrm{T} & \mathrm{A} & \mathrm{G} & \mathrm{S} & \mathrm{E} & \mathrm{P} & \mathrm{E} & \mathrm{S} & \mathrm{S} & \mathrm{S} & \mathrm{Y} & \mathrm{R} & \mathrm{E} & \mathrm{N}\end{array}$

$>4$

336 TGC AGG AAA AGA AAA ATG AGT TCC AAG GAC AGC TGC CAA GAC ACA GCA 383 $\begin{array}{llllllllllllllll}C & \mathbb{R} & \mathrm{K} & \mathbf{R} & \mathrm{K} & \mathrm{M} & \mathrm{S} & \mathrm{S} & \mathrm{K} & \mathrm{D} & \mathrm{S} & \mathrm{C} & \mathrm{Q} & \mathrm{D} & \mathrm{T} & \mathrm{A}\end{array}$

$>4$

384 GGG AAC TGT CCA GAA AAG GAG TGC AGC TTG TCA TTG AAT AAA AAA TCA 431

$\begin{array}{llllllllllllllll}G & N & C & P & E & K & E & C & S & L & S & L & N & K & K & S\end{array}$

C

432 AGA TCC TCC ACT GCT GTG CAC AAC AGT GAA ATC CAG GAG ACC TGT GAT 479

$\begin{array}{llllllllllllllll}R & \mathrm{~S} & \mathrm{~S} & \mathrm{~T} & \mathrm{~A} & \mathrm{~V} & \mathrm{H} & \mathrm{N} & \mathrm{S} & \mathrm{E} & \mathrm{I} & \mathrm{Q} & \mathrm{E} & \mathrm{T} & \mathrm{C} & \mathrm{D}\end{array}$

G

G

480 GCC CAC CAT AGG GGA CAT TCC AGG GCT TGC ACT GGG CAC AGC AAg CGG 527

$\begin{array}{llllllllllllllll}A & \mathrm{H} & \mathrm{H} & \mathrm{R} & \mathrm{G} & \mathrm{H} & \mathrm{S} & \mathrm{R} & \mathrm{A} & \mathrm{C} & \mathrm{T} & \mathrm{G} & \mathrm{H} & \mathrm{S} & \mathrm{K} & \mathbf{R}\end{array}$

528 CAT AGG TCT CGG GCC CTA GGA GTC CAA ACA CCG TCA ATT CGA AAA AGC 575

$\begin{array}{llllllllllllllll}\mathrm{H} & \mathrm{R} & \mathrm{S} & \mathrm{R} & \mathrm{A} & \mathrm{L} & \mathrm{G} & \mathrm{V} & \mathrm{Q} & \mathrm{T} & \mathrm{P} & \mathrm{S} & \mathrm{I} & \mathrm{R} & \mathrm{K} & \mathrm{S}\end{array}$

576 TTG GTG ACT TCT GTG CGA GCT ATG TCA GAG GCT GTT TAT CAA GAC CTA 623 $\begin{array}{llllllllllllllll}\mathrm{L} & \mathrm{V} & \mathrm{T} & \mathrm{S} & \mathrm{V} & \mathrm{R} & \mathrm{A} & \mathrm{M} & \mathrm{S} & \mathrm{E} & \mathrm{A} & \mathrm{V} & \mathrm{Y} & \mathrm{Q} & \mathrm{D} & \mathrm{L}\end{array}$

624 GCC CAG GTG TGG GCA CAG CAG ATC CAT TCT CCA CTT ACC TGT GAG CAG 671

$\begin{array}{llllllllllllllll}A & Q & V & \text { W } & A & Q & Q & I & H & S & P & L & T & C & E & Q\end{array}$

672 CTG ACA CTG CTC ACT CGG CTC CGG GGG CCT CTG TGT GCC CAG GTG CAG 719 $\begin{array}{lllllllllllllllll}\mathrm{L} & \mathrm{T} & \mathrm{L} & \mathrm{L} & \mathrm{T} & \mathrm{R} & \mathrm{L} & \mathrm{R} & \mathrm{G} & \mathrm{P} & \mathrm{L} & \mathrm{C} & \mathrm{A} & \mathrm{Q} & \mathrm{V} & \mathrm{Q}\end{array}$

720 ACC TTG TAT TCC ATG GCC ACC CAG GCA GCT TAT GTC TTC CCT GCT GAG 767 $\begin{array}{llllllllllllllll}\mathrm{T} & \mathrm{L} & \mathrm{Y} & \mathrm{S} & \mathrm{M} & \mathrm{A} & \mathrm{T} & \mathrm{Q} & \mathrm{A} & \mathrm{A} & \mathrm{Y} & \mathrm{V} & \mathrm{F} & \mathrm{P} & \mathrm{A} & \mathrm{E}\end{array}$

768 AGC TGG CTT GTC CCA GCC ACA CTG CCA GGT CCT GGG GAA TCA GCC CTG 815 $\begin{array}{llllllllllllllll}\mathrm{S} & \mathrm{W} & \mathrm{L} & \mathrm{V} & \mathrm{P} & \mathrm{A} & \mathrm{T} & \mathrm{L} & \mathrm{P} & \mathrm{G} & \mathrm{P} & \mathrm{G} & \mathrm{E} & \mathrm{S} & \mathrm{A} & \mathrm{L}\end{array}$

816 GAT AGA GAA GCC CAT CCC TTC CCT GGG CAG GAG ATA ACT GAG ACT GTC 863

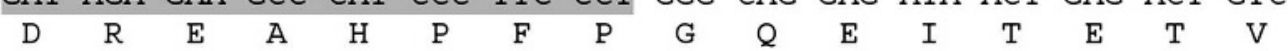

864 AGT GGA TCA GAT GAG GCT AAG CTG TGA GCA CCC TGA CCC TAT TCA GCA 911 $\begin{array}{lllllllll}S & G & S & D & E & A & K & \text { L } & \text { * }\end{array}$

Figure 2A CDNA sequence of the chromosome 4 copy of FRG2. The predicted FRG2 protein sequence is shown below the DNA sequence. Arrowheads $(>)$ indicate the first nucleotide following the splice junctions. A splice variant obtained by a second CAG triplet at the splice acceptor site of exon 4 is also indicated. The polymorphisms resulting in amino acid changes between the chromosome 4 and chromosome 10 copies in the ORF are depicted above the chromosome 4 sequence. The potential NLS and PTS1 signals are in bold while the polyadenylation signals are underlined. The LINE sequence is shaded. 
$\mathrm{NH}_{4} \mathrm{Cl}$ for $10 \mathrm{~min}$, and washed again in PBS/1\% BSA. After incubation with the first antibody in PBS/1\% BSA for $1 \mathrm{~h}$, coverslips were washed with $\mathrm{PBS} / \mathrm{1} \% \mathrm{BSA}$ and incubated with the second antibody for $30 \mathrm{~min}$. Subsequently, they were washed once with $\mathrm{PBS} / 1 \%$ BSA and once in PBS, dehydrated and embedded in Vectashield. The entire procedure was done at room temperature. Antibodies were used as follows: monoclonal M2 anti-FLAG (Sigma-Aldrich, St Louis, MO, USA) 1:5000, monoclonal anti-VSV-tag P5D4 (gift from Dr J Franssen, Nijmegen, The Netherlands) 1:3000, monoclonal anti-desmin (Monosan, The Netherlands) 1:100, and rabbit-anti-mouse Alexa 594 (Molecular Probes, Eugene, OR, USA) 1:1000.

\section{Fluorescence in situ hybridisation (FISH) on metaphase chromosomes}

Metaphase chromosome spreads of cultured control lymphocytes were hybridised with a $5.2 \mathrm{~kb}$ SmaI-XhoI fragment from cosmid 23D11 on which the FRG2 gene resides. The probe was labelled by nick translation with biotin-16-dUTP (Roche). ${ }^{38}$ Hybridisation, washing, and staining were performed as described previously. ${ }^{39}$

\section{RESULTS}

\section{Identification of $F R G 2$}

Computer aided exon prediction programs revealed the presence of four putative exons within a $3 \mathrm{~kb}$ genomic interval approximately $37 \mathrm{~kb}$ proximal to the D4Z4 repeat array. This predicted exon cluster was named $F R G 2$, for FSHD Region Gene 2. In each predicted exon, primers were designed for RT-PCR analysis. The intron-exon structure of FRG2 was defined using the constitutively expressed FRG2 (see under "Expression analysis of $F R G 2^{\prime \prime}$ ) in the hamsterhuman hybrid cell line GMI1687, which retained only human chromosome 4 . The cDNA products were sequenced and compared to the genomic sequence of the chromosome 4 specific PAC clone RCPI-1-226K22 (acc. no. AF146191).
FRG2 is composed of four exons and encodes an mRNA of $2084 \mathrm{bp}$ (figs 1 and 2). The ORF starts in exon 1 , ends in exon 4 , and encodes a putative protein of 278 amino acids. By 5' and $3^{\prime}$ RACE, the transcription initiation and two polyadenylation sites were identified, respectively. Both polyadenylation signals, $48 \mathrm{bp}$ apart, are used. No alternative splicing was observed except for the use of both acceptor sites created by a CAG doublet in exon 4 . This splice variation does not change the ORF, but creates an additional alanine codon. Using PSORT (http://psort.nibb.ac.jp), two potential nuclear localisation signals (NLS) at amino acid positions 96 (RKRK) and 157 (KRHR) were predicted as well as a peroxisomal targeting signal (PTS1) at the carboxyterminal end of the protein. ${ }^{40}{ }^{41}$ The complete cDNA sequence of FRG2 is shown in fig $2 \mathrm{~A}$ and $\mathrm{B}$. The putative FRG2 protein does not show significant homology to known proteins in the databases. A partial LINE sequence was identified within the ORF of FRG2. Significant homology outside this LINE element was found with only a few ESTs and IMAGE clones isolated from various tumour tissues and blood lymphocytes.

As observed previously, copies of sequences from this subtelomeric chromosomal region are dispersed throughout the genome. ${ }^{12} 313242$ Homologues of FRG2 were assigned to multiple chromosomal loci by PCR amplification using FRG2 primers $2 \mathrm{f}$ and $3 \mathrm{r}$ (fig 1 ). Closely related sequences were identified on chromosomes 1, 4, 8, 10, 18, and 20 (data not shown). FISH analysis on metaphase spreads of human fibroblasts using a highly homologous $5 \mathrm{~kb}$ genomic FRG2 probe derived from chromosome 10 showed strong hybridisation to the 4qter and 10qter regions, as well as weaker signals on chromosome 19 or 20q12. Sometimes weak signals were also detected on chromosome 1 (centromeric) and the $\mathrm{p}$ arms of the acrocentric chromosomes (data not shown). BLAST searches using the genomic sequence of FRG2 revealed additional homologues sequences on chromosomes $3,7,16$, and 22. It must be noted here that the assignment of $\mathrm{BAC}$ and PAC sequences to specific chromosomes are often

912 GAG ATG CAG CTC TGG GAA TGA GAA CAA GGA TCT GCT TCT TCT CAG ATT 959

960 CTT CCA GAT GAC CAG CAG TGA CAA TTT TAG ACA CAC TGT GTT AAT AAA 1007

1008 TGA CAG AAC CTG AAG AAG TCA TAG GAA AGA AAC TTG AGC GGT ATA CTC 1055

1056 AGA ATG GTG AGA GCC CTG AAT TTT GCA GAC CGC TAA GAC TAT AGA CAA 1103

1104 ATT TTA TAT TTC ATG TTA GAC ATT TGA TGC CTT TTG GAT GTC TGA TGA 1151

1152 CAG TCA TGC ATT TCT ATA TAA TCA GAA AAA CAT TAG AAT GTA ATC GTG 1199

1200 AAT TTG CAT ATT TTA GAT TGT AGA AAA GTA AAT ATA AAA TTA TGT GCT 1247

1248 CCT TTT TTG TTT TTT TTT TTT TTT GAG ACA GTC TTG CTA TGT TAC CCA 1295

1296 GGC TGG AGT GCA GTG GCA CAA TCT TAG CTC ACT GCA ACC TCT GCT TCC 1343

1344 TGG GTT CAA ACA ATT CTC ATG CCT CAG CCT CCC AAG CAG CTG GGA CTA 1391

1392 CAG GCA TGT ACT GCT ATG CCT GGC TAA TTT TTT TTT TCC TGT ATT GTT 1439

1440 AGT AGA GAC AGA GTT TTG TCA CTT TGG CCA GGT TGG CCT CGA ACT CAG 1487

1488 GTG ATC TGC CAG CCT CCG CCT CCC AAC GTG CTG GGA TTA CAG GCA TGA 1535

1536 GCC GCC TTA CCA AGA AAT TGC TTC TCT TTT AAT CCA GAA AAG GTT GTA 1583

1584 GGC TCT CAC TCT TCC AGC CTG AAC CCA TGG AGT ACT AAT ATC CAC AAA 1631

1632 CCA TTA ATA GCA CTC CCT GTG GGA AAA TGT CTA TAT ATT TTT AGT TTG 1679

1680 ATA TAA TTA TAG TAA AAT TAC TAT GCA AGC TGT TTA CTT TTA ATA TTT 1727

1728 CTA CAT AAA ATT TAA GTC AAG ATA TAG TAA ATG GTA AAT GAT TGT ACT 1775

1776 TAT TTA TTG ACC TGC CTC ATG TTT CAT TTC ATT TTA AAC ATC CTA AAT 1823

1824 TTA TAT TTT ATT ATA TTT TAT ACA TTT CAA TTG ATT GTA CTA TAT TGC 1871

1872 AGG ATA TGG AGA TTT CAT CAC GTA CTA CAA TAC AGT GTA TTT TGT TAT 1919

1920 ATT TGA CGT ATA TTC TAC TTG TAT TTT GTA CTG AGA TCA TAC ACT ATT 1967

1968 TCA TTA TCT AAG TGT ATT AAT TGT TTG GTT GCT TTA TAA TTT TCA TTT 2015

2016 TAT GTA ATG AAA TAA ACA ATG TTG TTT GGA ATT TTA AAT TTC TTT CAT 2063

2064 ATG GAA TTT GTA TTT AAT AAA

2084

Figure 2B CDNA sequence of the chromosome 4 copy of FRG2 (continued). 

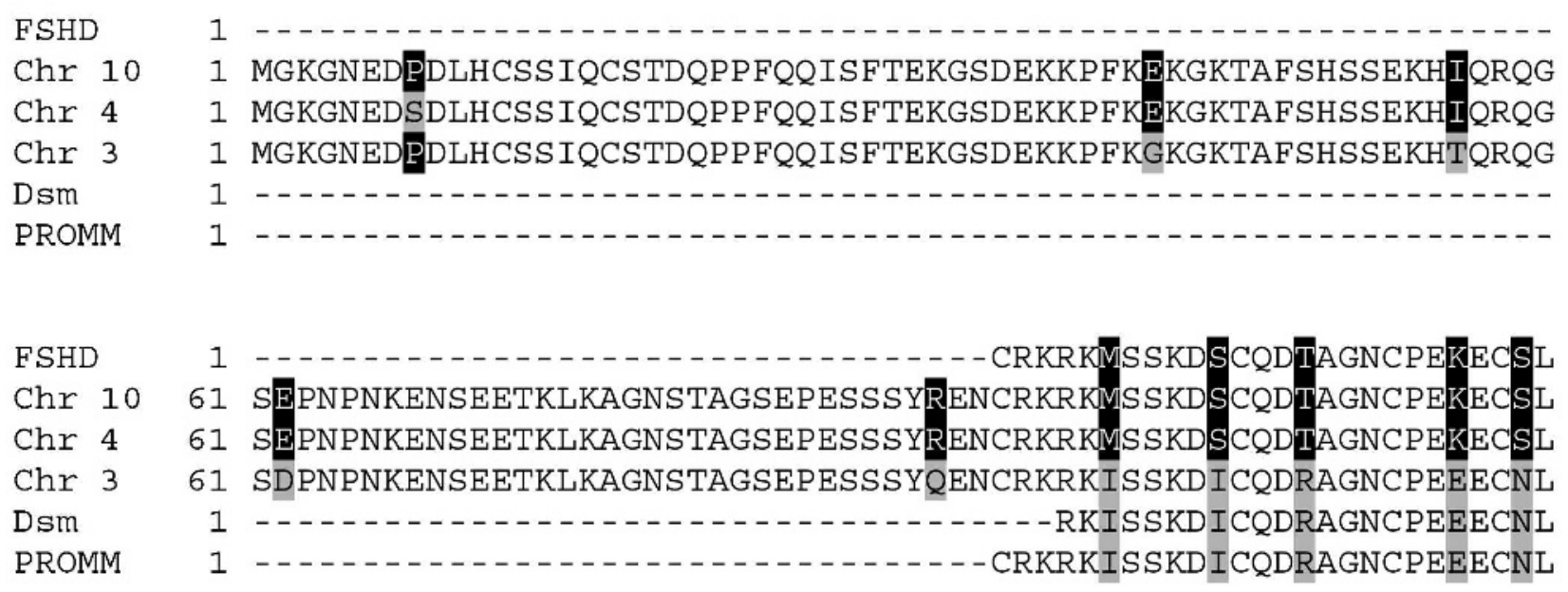

$\begin{array}{lrll}\text { FSHD } & 27 & \text { SLNKKSRSSTPVHNSEIQETCDAHHRGRSRACTGRSKRHRSRALGVQTPSIRKSLVTSVR } \\ \text { Chr } 10 & 121 & \text { SLNKKSRSSTPVHNSEIQETCDAHHRGRSRACTGRSKRHRSRALGVQTPSIRKSLVTSVR } \\ \text { Chr } 4 & 121 & \text { SLNKKSRSSTAVHNSEIQETCDAHHRGHSRACTGHSKRHRSRALGVQTPSIRKSLVTSVR } \\ \text { Chr } & 121 & \text { TLNKKSRSSTAVHNSEIQETCDAHHRGSSRACTGRSKRHRSRALEVQTPSLRKSLVTSVR } \\ \text { Dsm } & 24 & \text { TLNKKSRSSTAVHNSEIQETCDAHHRGSSRACTGRSKRHRSRALEVQTPSLRKSLVTSVR } \\ \text { PROMM } & 27 & \text { TLNKKSRSTIAVHNSEIQETCDAHHRGSSRACTGRSKRHRSRALEVQTPSLRKSLVTSVR }\end{array}$

FSHD 87 AMSEAVYQDLAQVWAQQIHSPLTCE-- Chr 10181 AMSEAVYQDLAQVWAQQIHSPLTCEQLTLLTRLRGPLCAQVQTLYSMATQAAYVFPAESW Chr 4181 AMSEAVYQDLAQVWAQQIHSPLTCEQLTLLTRLRGPLCAQVQTLYSMATQAAYVFPAESW Chr 3181 AMSEAVYQDLAQVWAQQIHSPLTCEQLTLLTRLRGPLCAQVQTLYSMATQAAYVFPAESW Dsm 84 AMSEAVYQDLAQVWAQQIHSPLT PROMM 87 AMSEAVYQDLAQVWAQQIHSPLTCE- - $\ldots \ldots \ldots \ldots$

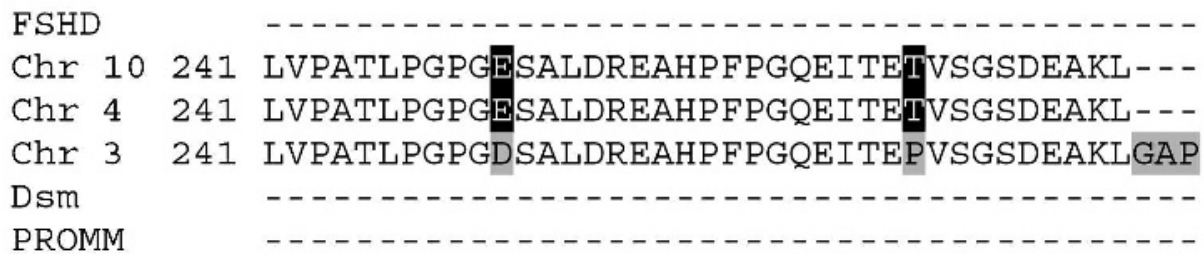

Figure 3 Comparison of the predicted protein sequences derived from the FRG2 genes on chromosomes 10, 4, and 3 (complete ORF), as well as partial sequences obtained by RT-PCR on myoblasts of FSHD, DSM, and PROMM patients. Black and grey boxes mark amino acids that differ between the variants.

ambiguous due to pericentromeric and subtelomeric plasticity. ${ }^{43}$ Sequence comparisons demonstrated that the FRG2 copies on chromosomes 4 and 10 are highly homologous to each other, whereas homologues assigned to chromosomes 3 and 22 encode identical proteins but display a total of 20 amino acid substitutions compared to the chromosome 4 variant (fig 3). FRG2-like sequences mapping to other chromosomes were often incomplete, displayed lower homology (varying from 65 to $90 \%$ at the nucleotide level), and were mostly found in subtelomeric or pericentromeric regions.

Since only the copies on chromosomes 4 and 10 are closely associated with intact D4Z4 repeat arrays, we further focused on these two copies. Sequence comparison of the chromosome 4 and 10 loci revealed five nucleotide mismatches in the ORF. All of these, except for the silent nucleotide difference at position 584, result in amino acid substitutions (chromosome $4 v 10$ ): a Ser8Pro at position 75, Alal31Pro at position 444, His 148Arg at position 496, and His155Arg at position 517, respectively (fig 3 ).

\section{Expression analysis of FRG2}

Expression analysis by RT-PCR of nine monochromosomal cell hybrids containing either human chromosome $4(n=5)$ or human chromosome $10(\mathrm{n}=4)$ as their only human component, revealed constitutive FRG2 expression only in GM11687 (chromosome 4, data not shown). Peripheral blood lymphocytes and fibroblasts from FSHD patients and controls, and control brain and fetal muscle were used as a template to test for FRG2 expression by RT-PCR using primers in each exon (fig 1). Muscle biopsies of seven independent FSHD patients and six healthy controls were analysed by 

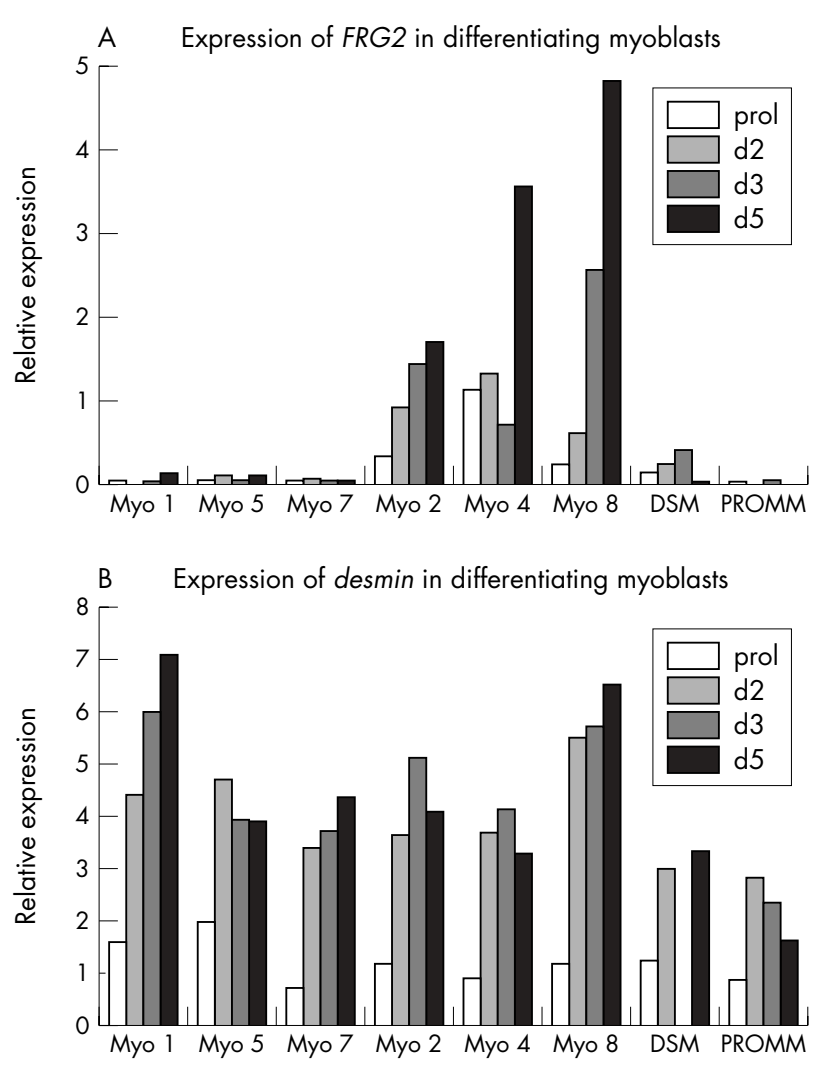

Figure 4 Relative expression levels of FRG2 and desmin were determined by quantitative real time RT-PCR on DNase-treated RNA from myoblast cultures of three healthy control individuals (Myo 1, 5, and 7), three FSHD patients (Myo 2, 4, and 8), a patient with DSM, and a PROMM patient. RNA was isolated during proliferation (prol) of primary myoblast cultures, and at three time points after the induction of differentiation by serum deprivation (day 2, 3, and 5). FRG2 and desmin transcript levels were normalised against $18 S$ rRNA transcript levels. FRG2 primers were specific for chromosomes 4 and 10. Desmin was amplified to test the myogenic character of the cell cultures. All primer combinations spanned one intron.

radioactive RT-PCR. No expression of FRG2 was detected in any of these tissues. Quantitative real time RT-PCR on the latter set of muscle samples revealed that FRG2 mRNA was absent or barely detectable in the irreproducible range (mean Ct value $F R G 2=38.4$ (SD 1.5); $\beta$-actin $=20.8$ (SD 0.9)). Moreover, if any expression was detected, no differences in FRG2 expression levels were found between control (mean $\mathrm{Ct}=38.6(\mathrm{SD} 1.6))$ and FSHD (mean $\mathrm{Ct}=38.3(\mathrm{SD} 1.5))$ muscle, contradicting the specific and repeat-length dependent upregulation in FSHD muscle recently reported by Gabellini et al. ${ }^{19}$

Next, myoblast cultures isolated from skeletal muscle biopsies were analysed. As described before, ${ }^{44}$ myoblast cultures of FSHD patients are phenotypically different from healthy myoblasts. FSHD myoblasts are characterised by a swollen cytoplasm, large vacuoles adjacent to the nucleus, and a higher percentage of cells with a necrotic appearance. ${ }^{44}$ Furthermore, FSHD myoblasts appear to have a reduced replicative capacity and a morphology resembling senescence. $^{45}$ Expression of $F R G 2$ was analysed in myoblast cultures of FSHD patients, non-FSHD muscular dystrophy patients (PROMM and DSM), and healthy controls. Nested RT-PCR using primers that recognise all homologues show barely or no detectable FRG2 expression in proliferating myoblasts. However, after induction of differentiation by serum starvation, expression of FRG2 was demonstrated in myoblasts of FSHD patients and to a lesser extent in the nonFSHD myopathy patients, but not in healthy controls (results not shown). These data were confirmed and quantified by real time RT-PCR using FRG2 primers specific for chromosome 4 and 10. Expression of desmin demonstrated the presence of myogenic cells in the differentiating primary myoblast cultures (fig 4). Additionally, immunohistochemical analysis revealed that virtually all $(80-100 \%)$ cells in the proliferating myoblast cultures of patients and controls stained positive for desmin ${ }^{44}$ (data not shown).

\section{Chromosomal origin of transcription}

To determine in more detail the chromosomal origin of the FRG2 transcripts in differentiating myoblasts, the RT-PCR products of all patient cell lines were directly analysed on an ABI377 DNA sequencer. Interestingly, the FRG2 transcripts in differentiating myoblasts of FSHD patients were mainly derived from chromosome 10 and to a lesser extent from chromosome 4. FRG2 transcripts in non-FSHD myopathies were however not derived from chromosome 4 or 10, but compatible with FRG2 sequences derived from chromosome 3 or 22, which are identical. In order to show that the sequence variations that we observed between the different chromosomes are not merely randomly occurring polymorphisms, exon 4 of FRG2 was amplified by PCR from independent sources. Direct sequence analysis of the PCR products revealed that in five independent sources of chromosome 4, the exon 4 sequences are $100 \%$ identical. The same holds true for four independent sources of chromosome 10. Moreover, among all the homologous sequences identified by BLAST search, none was $100 \%$ homologous to the chromosome 4 or 10 sequence, indicating that the chromosome 4-type and 10type $F R G 2$ sequences are indeed chromosome specific.

\section{Promoter study}

In order to characterise the putative promoter region preceding the FRG2 gene, we designed and generated luciferase reporter constructs. In TE671 human rhabdomyosarcoma cells, a transiently transfected reporter construct carrying the $3.4 \mathrm{~kb}$ region immediately preceding the $F R G 2$ gene on chromosome 4 in the forward orientation displayed 125 times higher activity than the same region cloned in the inverted orientation. Assays using only $800 \mathrm{bp}$ predicted promoter region containing the CAAT and TATA boxes showed 254-fold induction of luciferase activity as compared to the $3.4 \mathrm{~kb}$ inverted construct (results not shown).

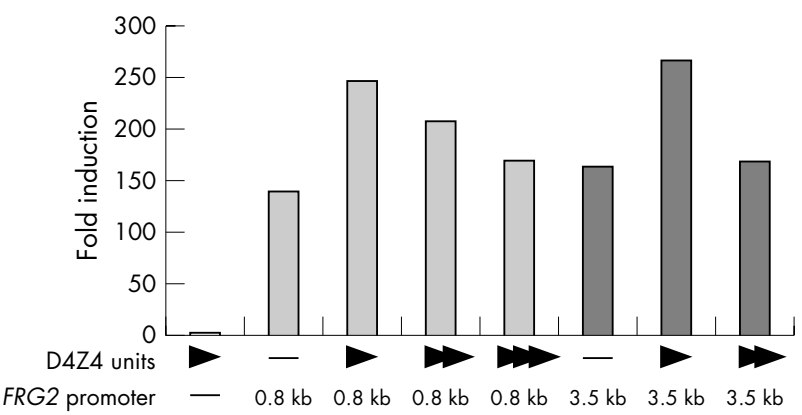

Figure 5 FRG2 promoter assay and influence of D4Z4 in U2OS cells. Luciferase activity per unit $\beta$-galactosidase of the transfected constructs was determined relative to the activity of the empty $\mathrm{pGL} 3$ basic vector. One D4Z4 unit (indicated by 1 ) cloned into pGL3basic without an FRG2 promoter resulted in a 2.4 fold induction of luciferase activity. The high activity of each promoter in the presence of one D4Z4 unit is inhibited upon addition of more D4Z4 units. Similar results were obtained for TE671 human rhabdomyosarcoma cells. 


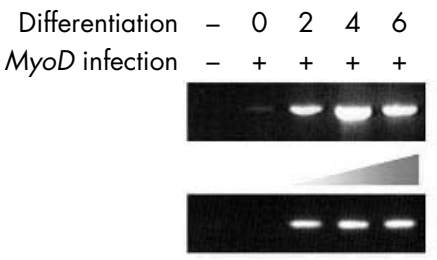

FSHD

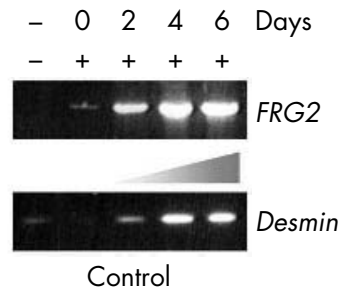

Figure 6 RT-PCR using FRG2 specific primers if and $4 \mathrm{r} 2$ on RNA from fibroblasts of an FSHD patient (91RD215) and a healthy control individual (VH10) undergoing forced myogenesis by adenoviral MyoD expression. Expression of FRG2 was analysed during proliferation (-MyoD; - Differentiation), 2 days after infection but before differentiation (+MyoD; 0 Days) and at 2, 4, and 6 days after the induction of differentiation. The degree of myogenic differentiation is indicated by the triangles. As a control for myogenesis, desmin was amplified.

To test their influence on the activity of the FRG2 promoter, up to three D4Z4 repeat units were directionally cloned $5^{\prime}$ of the 0.8 and $3.4 \mathrm{~kb} F R G 2$ promoter sequences in the luciferase reporter constructs and transiently transfected into TE671 and U2OS human osteosarcoma cells. Interestingly, the highest luciferase activity was observed when transfecting constructs containing one D4Z4 unit 5' of an FRG2 promoter sequence. Both for the 0.8 and the $3.4 \mathrm{~kb}$ promoters tested, increasing the numbers of D4Z4 units resulted in a stepwise reduction of luciferase activity, indicating that the presence of D4Z4 repeat units can inhibit the activity of the FRG2 promoter (fig 5).

\section{FRG2 expression in forced myogenesis}

To study the potential involvement of FRG2 in myogenesis, fibroblast cultures of FSHD patients and healthy controls were analysed for $F R G 2$ expression before and after infection with an adenovirus carrying the murine MyoD gene. To confirm the initiation of forced myogenesis, expression of muscle specific desmin was analysed by RT-PCR. Before infection and at four time points after infection and differentiation, RNA was isolated and analysed for the presence of FRG2. Fibroblasts did not express FRG2 during proliferation or upon infection with MyoD. However, at all time points after induction of differentiation by serum starvation, strong FRG2 expression was observed in FSHD patient and healthy control fibroblasts (fig 6). This expression of FRG2 originated predominantly from chromosome 10 and to a lesser extent from chromosome 4 (data not shown).

\section{Subcellular localisation and morphology upon transfection of FRG2}

Since the putative FRG2 protein contains a potential carboxyterminal peroxisomal PTS1 signal and two putative nuclear localisation (NLS) signals, its subcellular localisation was studied. The FRG2 protein was fused to aminoterminal VSV, FLAG, and GFP tags, respectively, to minimise the artificial effects of the tag on the cellular localisation. We transiently transfected several cell lines including COS-1, TE671, and human myoblasts. All transfections showed a nuclear, but no peroxisomal localisation of FRG2. The staining varied from a homogeneous to a granular nuclear pattern (fig 7), but no specificity for a particular subnuclear compartment was established. Interestingly, despite the low number of transfected myoblasts, overexpression of EGFPFRG2 apparently causes morphological changes in FSHD and control myonuclei ranging from necrotic, pyknotic to fused and clumped nuclei (fig 7).

\section{DISCUSSION}

In this paper, we report on the isolation and characterisation of a novel gene, FRG2, in the FSHD candidate region. FRG2, at only $37 \mathrm{~kb}$ from the D4Z4 repeat array, is the most telomeric gene identified in this region and thus closest to the D4Z4 repeats. It consists of four exons and computer analyses
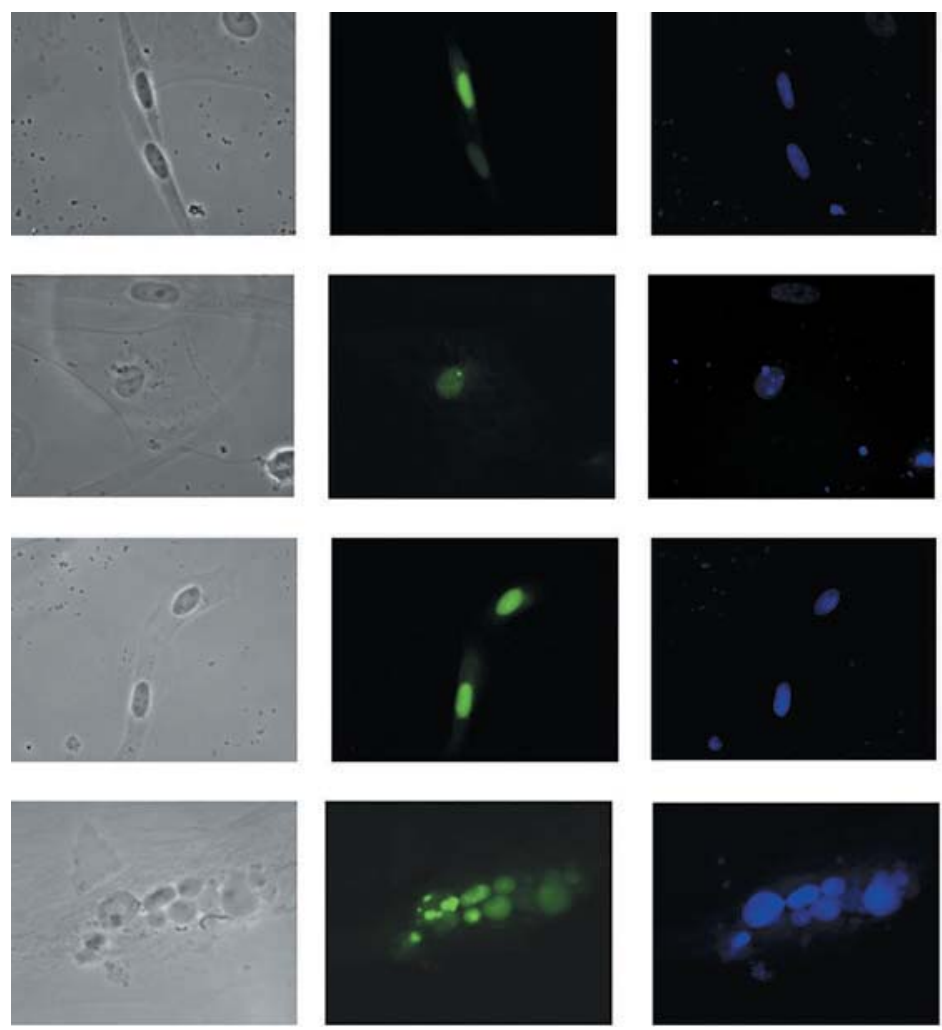
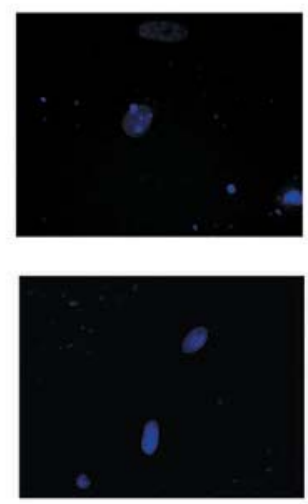

Control GFP

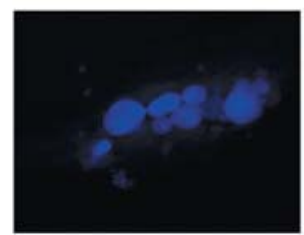

Figure 7 Cellular localisation of EGFPFRG2 and morphology of the cells. Proliferating healthy control (myo 5) and FSHD (myo 8) myoblasts were transiently transfected with pEGFP or pEGFP-FRG2 and directly allowed to differentiate for 3 days. EGFP-FRG2 protein is localised in the nucleoplasm and may be actively transported to untransfected nuclei after fusion into

Control GFP-FRG2 multinucleated cells. FSHD and control myotubes overexpressing EGFP-FRG2 seem to have an altered nuclear morphology compared to myotubes transfected with pEGFP. The foci observed in some nuclei are probably caused by the strong overexpression of the fusion protein as they do not localise to a specific structure. Left column: Phase contrast images. Middle column: Fluorescence image showing EGFPFRG2 fusion protein distribution in the same cell. Right column: DAPI staining of the corresponding nuclei. 
predict a promoter including CAAT and TATA boxes preceding the gene. This putative promoter was shown to be very active in a luciferase reporter assay. The presence of increasing numbers of D4Z4 units resulted in gradual reduction of $F R G 2$ promoter activity, supporting the concept that D4Z4 is repressing transcriptional activity in cis, possibly through the action of the D4Z4 repressor complex. ${ }^{19}$ However, in concordance with previously published data, ${ }^{20}$ also transactivating elements should be present in D4Z4 as a single D4Z4 unit already drives luciferase activity (fig 5). Our transient transfection assays with FRG2 expression constructs suggested a nuclear localisation for the FRG2 protein, as predicted by the NLS signals. Non-consensus peroxisomal targeting signals (PTS-1), such as the AKL motif in FRG2, only function in combination with specific additional amino acid residues. ${ }^{46}$ Their absence in $F R G 2$ may explain its nuclear rather than peroxisomal localisation.

As shown by our PCR, FISH, and BLAST search studies, homologous genomic FRG2 segments are dispersed over the genome. The D4Z4 linked FRG2 sequences from chromosomes 4 and 10 are almost identical to each other, whereas other homologues are incomplete or only remotely related to the FRG2 sequence originating from chromosome 4. These homologues are often found in pericentromeric or subtelomeric regions that are frequently involved in ectopic chromosomal rearrangements. ${ }^{43}$ The presence in these regions of genes, such as members of the human olfactory gene family, has prompted others to suggest that subtelomeres serve to generate gene diversity. ${ }^{43}{ }^{47}$

Despite the widespread presence of FRG2-like sequences, the FRG2 genes on chromosome 4 and 10 have several properties that make them attractive genes for involvement in FSHD pathogenesis. First, the FRG2 genes on both chromosome 4 and 10 are closely linked to the D4Z4 repeat. Deletion of repeat units from chromosome 4 is the primary event in FSHD. Second, the FRG2 promoter can, in principle, drive expression to very high levels and the gene is constitutively expressed in the monochromosomal cell line GM11687, but undetectable in a variety of human tissues. This demonstrates that the copies on chromosome 4 and 10 have the potential to be expressed under tight regulatory control in vivo. In concordance with this, our promoter studies demonstrate that the FRG2 promoter is sensitive to the presence of D4Z4 repeat units. Third, the expression profile: our studies in myoblast cultures show that copies of FRG2 compatible with chromosome 4 and 10 origins are expressed only in differentiating, but not proliferating myoblasts of FSHD patients, while healthy control myoblasts failed to express any copy of $F R G 2$. In contrast, differentiating myoblasts of non-FSHD myopathies express a distantly related copy of FRG2 (see below). Fourth, its putative involvement in myogenesis: FRG2 expression is absent in all tissues tested except differentiating myoblasts and an evident transcriptional upregulation is detected after adenoviral $M y o D$ expression in fibroblasts. Forced expression of $M y o D$ and other members of the myogenic family of basic helix-loop-helix transcription factors activates a myogenic program in fibroblasts. ${ }^{48}$ It has also been demonstrated that $M y o D$ can remodel chromatin in the regulatory region of skeletal muscle genes and initiate endogenous gene transcription. ${ }^{49}$ This may explain how FRG2 expression can be detected upon strong adenoviral $M y o D$ overexpression in healthy fibroblasts, but not in normal, untreated myoblasts.

Sequence comparisons of various FRG2 copies revealed that the FRG2 protein from chromosome 10 differs in only four amino acids from the chromosome 4 sequence. Two of these changes introduce prolines that may change the conformation of the protein. In contrast, the homologues identified on chromosomes 3 and 22 encode putative proteins with

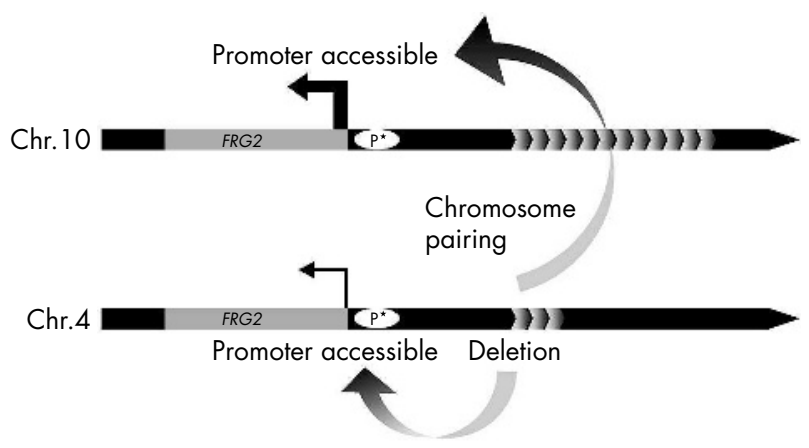

Figure 8 Transvection hypothesis. Partial deletion of the D4Z4 repeat array on the chromosome $4 q$ subtelomeric region changes the local chromatin structure and its interaction with the nuclear envelope, enabling expression of $F R G 2$ to a low level. Upon pairing of

chromosomes 4 and 10, transcription of FRG2 from chromosome 10 is transactivated.

20 amino acid substitutions compared to the chromosome 4 variant. A number of these amino acid replacements involve polarity changes, possibly affecting protein function. FRG2 proteins from chromosome 4 (or 10) may therefore function (or even dysfunction) differently from the 3/22-like FRG2 copy that is expressed in non-FSHD myopathies. A recently published gene expression profiling study suggested that FSHD exhibits a unique defect in myogenic differentiation. ${ }^{14}$ These and our observations that the nuclear morphology of healthy and FSHD myoblasts transfected with FRG2 tends to deteriorate, leads us to speculate that aberrant expression of the chromosome 4 or 10 copy of FRG2 may very well be detrimental to myogenic differentiation and can thus play a causative role in the loss of muscle function seen in FSHD patients. The low levels of FRG2 expression from chromosome 3 or 22 in non-FSHD myopathies may then merely represent general muscular dystrophy related processes in these myoblasts. However, we cannot exclude that FRG2 expression is not a primary effect of D4Z4 deletion, but a secondary reaction of the FSHD myoblasts, albeit different from non-FSHD muscular dystrophies.

Radioactive RT-PCR failed to detect any expression of FRG2 in RNA isolated from seven independent FSHD and six healthy control muscle biopsies, while analysis of $\beta$-actin, desmin, GAPDH, and $18 S$ rRNA transcript levels confirmed the integrity of our RNA samples. Real time RT-PCR confirmed the (almost complete) absence of FRG2 transcripts in all of our biopsies, thereby failing to reproduce the repeat-length dependent upregulation of FRG2 expression in FSHD muscle as reported by Gabellini et al. ${ }^{19}$ Assuming a role of FRG2 in the differentiation of myoblasts, one possible explanation for this discrepancy may be that the level of regeneration in a biopsy is critical for the detection of FRG2 expression. It must, however, be noted here that others have likewise been unsuccessful in reproducing the upregulation of FRGI and ANTI expression in FSHD muscle also described by Gabellini et al. ${ }^{1450}$

A challenging finding is that in FSHD patient myoblasts FRG2 is expressed both from chromosome 4 and 10, while FSHD is only associated with a partial deletion of the D4Z4 repeat array on chromosome 4 . It has been demonstrated that chromosome pairing during interphase can lead to transcriptional activation of homologous genes in trans by transvection (reviewed in Pirrotta ${ }^{51}$ ). Interestingly, somatic pairing between the subtelomeric regions of chromosomes $4 \mathrm{q}$ and $10 \mathrm{q}$ is increased in FSHD patients compared to controls, possibly facilitating gene regulation by trans sensing effects. ${ }^{15}$ Moreover, D4Z4 repeats transfected into C2C12 myoblasts 
were shown to have a significant trans effect on myoblast differentiation. ${ }^{21}$ In a recent model, Winokur et $a l^{14}$ (and $\mathrm{S}$ Winokur, personal communication) suggest that aberrant gene expression in FSHD results from disturbed interaction of 4qtel with the nuclear envelope following contraction of the D4Z4 repeat array. Elaborating on this, we propose that partial deletion of the D4Z4 repeat array leads to a change in local chromatin structure and aberrant interaction of 4qtel with the nuclear envelope, enabling FRG2 expression in cis on chromosome 4 . In those FSHD cells where chromosomes 4 and 10 are somatically paired, activation of FRG2 expression may also occur in trans on chromosome 10, possibly via transvection (fig 8). The higher responsiveness of the chromosome 10 copy for FRG2 expression upon pairing and transvection may be explained by the close proximity of euchromatic sequences at $60 \mathrm{~kb}$ distance, whereas on chromosome 4 non-subtelomeric sequences are at least $500 \mathrm{~kb}$ further upstream. ${ }^{52}$

A partial deletion of D4Z4 on chromosome 10 however does not result in FSHD. A possible explanation lies in the observation that, unlike chromosome 4qtel, 10qtel is not normally localised to the nuclear periphery ( $\mathrm{S}$ Winokur, personal communication). It is currently unknown whether contracted D4Z4 repeats on chromosome 10 can also activate FRG2 in cis, and in trans on chromosome 4. FRG2 expression studies in patients with a deletion of the repeat array on chromosome 4 extending proximal to $F R G 2^{53}$ and in healthy individuals with an FSHD sized repeat array on chromosome 10 would support such a transvection mechanism for FRG2. Unfortunately, myoblasts of these individuals are currently not available to test this hypothesis.

\section{ACKNOWLEDGEMENTS}

The authors thank E Cuppen for providing us with the pSG8-VSV vector and $\mathrm{H}$ Dauwerse for performing FISH analysis.

\section{ELECTRONIC-DATABASE INFORMATION}

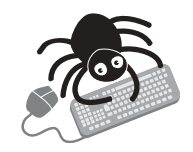

Information on PSORT is available from http:// psort.nibb.ac.jp

\footnotetext{
Authors' affiliations

T Rijkers, G Deidda*, S van Koningsbruggen, R J L F Lemmers, J C T van Deutekom, R R Frants, S M van der Maarel, Department of Human Genetics, Center for Human and Clinical Genetics, Leiden University Medical Center, Wassenaarseweg 72, 2333 AL Leiden, The Netherlands

M van Geel, Department of Dermatology, Academic Hospital Maastricht, Maastricht, The Netherlands

D Figlewicz†, Departments of Neurology and Neurobiology and Anatomy, University of Rochester Medical Center, Rochester, NY, USA J E Hewitt, Institute of Genetics, Queen's Medical Center, University of Nottingham, N97 2UH, Nottingham, UK

G W Padberg, Department of Neurology, University Hospital Nijmegen, PO Box 9101, 6500 HB Nijmegen, The Netherlands

This study was supported by the FSH Society Inc. (Marjorie Bronfman fellowship grants to SMVDM and TR), the Prinses Beatrix Fonds, the Netherlands Organization for Scientific Research (NWO), the Muscular Dystrophy Association, and the Dutch FSHD Foundation.

Conflict of interest: none declared.

${ }^{*}$ Current address: Institute of Cell Biology, CNR, 43 Viale Marx, 00137 Rome, Italy.

†Current address: Department of Neurology, University of Michigan, Ann Arbor, MI, USA.

The FRG2 cDNA sequence of chromosome 4 has been submitted to the
} GenBank database. The accession number is AY714545.
The cDNA sequence ( $5^{\prime}$ UTR and CRF) of the FRG2 homologue on chromosome 10 has also been submitted to the GenBank database. The accession number is AY744466.

\section{REFERENCES}

1 Funakoshi M, Goto K, Arahata K. Epilepsy and mental retardation in a subset of early onset $4 \mathrm{q} 35$-facioscapulohumeral muscular dystrophy. Neurology 1998:50(6): 1791-4

2 Padberg GW. Facioscapulohumeral disease [thesis]. Leiden: Leiden University, 1982.

3 Padberg GW, Frants RR, Brouwer OF, Wijmenga C, Bakker E, Sandkuiil LA. Facioscapulohumeral muscular dystrophy in the Dutch population. Muscle Nerve 1995;2:S81-4

4 Sarfarazi M, Wijmenga C, Upadhyaya M, Weiffenbach B, Hyser C, Mathews K, Murray J, Gilbert J, Pericak Vance M, Lunt P, Frants RR, Jacobsen S, Harper PS, Padberg GW. Regional mapping of facioscapulohumeral muscular dystrophy gene on $4 \mathrm{q} 35$ : combined analysis of an international consortium. Am J Hum Genet 1992;51(2):396-403.

5 Wiimenga C, Frants RR, Brouwer OF, Moerer P, Weber JL, Padberg GW. Location of facioscapulohumeral muscular dystrophy gene on chromosome 4. Lancet 1990;336(8716):651-3.

6 Wijmenga C, Hewitt JE, Sandkuijl LA, Clark LN, Wright TJ, Dauwerse HG, Gruter AM, Hofker MH, Moerer P, Williamson R, van Ommen GJ, Padberg GW, Frants RR. Chromosome 4q DNA rearrangements associated with facioscapulohumeral muscular dystrophy. Nat Genet 1992;2(1):26-30.

7 Van Deutekom JC, Wiimenga C, van Tienhoven EA, Gruter AM, Hewitt JE, Padberg GW, van Ommen GJ, Hofker MH, Frants RR. FSHD associated DNA rearrangements are due to deletions of integral copies of a $3.2 \mathrm{~kb}$ tandemly repeated unit. Hum Mol Genet 1993;2(12):2037-42.

8 Hewitt JE, Lyle R, Clark LN, Valleley EM, Wright TJ, Wiimenga C, van Deutekom JC, Francis F, Sharpe PT, Hofker M, Frants RR, Williamson R. Analysis of the tandem repeat locus D4Z4 associated with facioscapulohumeral muscular dystrophy. Hum Mol Genet 1994;3(8):1287-95

9 Lee JH, Goto K, Matsuda C, Arahata K. Characterization of a tandemly repeated 3.3-kb Kpnl unit in the facioscapulohumeral muscular dystrophy (FSHD) gene region on chromosome 4q35. Muscle Nerve 1995;2:6-13.

10 Lunt PW, Jardine PE, Koch MC, Maynard J, Osborn M, Williams M, Harper PS, Upadhyaya M. Correlation between fragment size at D4F104S1 and age at onset or at wheelchair use, with a possible generational effect, accounts for much phenotypic variation in $4 \mathrm{q} 35$-facioscapulohumeral muscular dystrophy (FSHD). Hum Mol Genet 1995;4(5):951-8.

11 Tawil R, Forrester J, Griggs RC, Mendell J, Kissel J, McDermott M, King W, Weiffenbach B, Figlewicz D. Evidence for anticipation and association of deletion size with severity in facioscapulohumeral muscular dystrophy. The FSH-DY Group. Ann Neurol 1996;39(6):744-8

12 Winokur ST, Bengtsson U, Feddersen J, Mathews KD, Weiffenbach B, Bailey H, Markovich RP, Murray JC, Wasmuth JJ, Altherr MR, Schutte BC. The DNA rearrangement associated with facioscapulohumeral muscular dystrophy involves a heterochromatin-associated repetitive element: implications for a role of chromatin structure in the pathogenesis of the disease. Chromosome Res 1994;2(3):225-34.

13 Jiang G, Yang F, van Overveld PG, Vedanarayanan V, van der MS, Ehrlich M. Testing the position-effect variegation hypothesis for facioscapulohumeral muscular dystrophy by analysis of histone modification and gene expression in subtelomeric 4q. Hum Mol Genet 2003;12(22):2909-21 .

14 Winokur ST, Chen YW, Masny PS, Martin JH, Ehmsen JT, Tapscott SJ, van der Maarel SM, Hayashi Y, Flanigan KM. Expression profiling of FSHD muscle supports a defect in specific stages of myogenic differentiation. Hum Mol Genet 2003;12(22):2895-907.

15 Stout K, van der Maarel S, Frants RR, Padberg GW, Ropers H-H, Haaf T. Somatic pairing between subtelomeric regions: implications for human genetic disease? Chromosome Res 1999;7:323-9.

16 Van der Maarel SM, Deidda G, Lemmers RJ, van Overveld PG, van der Wielen M, Hewitt JE, Sandkuiil L, Bakker B, van Ommen GJ, Padberg GW Frants RR. De novo facioscapulohumeral muscular dystrophy: frequent somatic mosaicism, sex-dependent phenotype, and the role of mitotic transchromosomal repeat interaction between chromosomes 4 and 10 . Am J Hum Genet 2000;66(1):26-35.

17 Lemmers RJ, van Overveld PG, Sandkuijl LA, Vrieling H, Padberg GW, Frants RR, van der Maarel SM. Mechanism and timing of mitotic rearrangements in the subtelomeric D4Z4 repeat involved in facioscapulohumeral muscular dystrophy. Am J Hum Genet 2004;75(1):44-53.

18 Van Overveld PG, Lemmers RJ, Sandkuijl LA, Enthoven L, Winokur ST, Bakels F, Padberg GW, van Ommen GJ, Frants RR, van der Maarel SM. Hypomethylation of D4Z4 in 4q-linked and non-4q-linked facioscapulohumeral muscular dystrophy. Nat Genet 2003;35(4):315-7.

19 Gabellini D, Green M, Tupler R. Inappropriate gene activation in FSHD. A repressor complex binds a chromosomal repeat deleted in dystrophic muscle. Cell 2002;110(3):339-48.

20 Gabriels J, Beckers MC, Ding H, De Vriese A, Plaisance S, van der Maarel SM, Padberg GW, Frants RR, Hewitt JE, Collen D, Belayew A. Nucleotide sequence of the partially deleted D4Z4 locus in a patient with FSHD identifies a putative gene within each $3.3 \mathrm{~kb}$ element. Gene 1999;236(1):25-32.

21 Yip DJ, Picketts DJ. Increasing D4Z4 repeat copy number compromises C2C12 myoblast differentiation. FEBS Lett 2003;537(1-3):133-8. 
22 Bakker E, Wiimenga C, Vossen RH, Padberg GW, Hewitt J, van der Wielen M, Rasmussen K, Frants RR. The FSHD-linked locus D4F104S1 (p13E11) on 4q35 has a homologue on 10qter. Muscle Nerve 1995;2:39-44.

23 Deidda G, Cacurri S, Grisanti P, Vigneti E, Piazzo N, Felicetti L. Physical mapping evidence for a duplicated region on chromosome 10gter showing high homology with the facioscapulohumeral muscular dystrophy locus on chromosome 4qter. Eur J Hum Genet 1995;3:155-67.

24 Van Deutekom JC, Bakker E, Lemmers RJ, van der Wielen MJ, Bik E, Hofker MH, Padberg GW, Frants RR. Evidence for subtelomeric exchange of $3.3 \mathrm{~kb}$ tandemly repeated units between chromosomes $4 \mathrm{q} 35$ and $10 \mathrm{q} 26$ : implications for genetic counselling and etiology of FSHD1. Hum Mol Genet 1996;5(12): 1997-2003

25 Van Overveld PG, Lemmers RJ, Deidda G, Sandkuijl L, Padberg GW, Frants RR, van der Maarel SM. Interchromosomal repeat array interactions between chromosomes 4 and 10: a model for subtelomeric plasticity. Hum Mol Genet 2000;9(19):2879-84.

26 Lemmers RJL, de Kievit $P$, van Geel M, van der Wielen MJ, Bakker E, Padberg GW, Frants RR, van der Maarel SM. Complete allele information in the diagnosis of facioscapulohumeral muscular dystrophy by triple DNA analysis. Ann Neurol 2001;50(6):816-9.

27 Zhang $Y$, Forner J, Fournet S, Jeanpierre M. Improved characterization of FSHD mutations. Ann Genet 2001;44(2):105-10.

28 Van Geel M, van Deutekom JC, van Staalduinen A, Lemmers RJ, Dickson MC, Hofker MH, Padberg GW, Hewitt JE, de Jong PJ, Frants RR. Identification of a novel beta-tubulin subfamily with one member (TUBB4Q) located near the telomere of chromosome region $4 \mathrm{q} 35$. Cytogenet Cell Genet 2000;88(3-4):316-21

29 Van Koningsbruggen S, Dirks RW, Mommaas AM, Onderwater J, Deidda G Padberg GW, Frants RR, van der Maarel SM. FRGIP is localized in the nucleolus, Cajal bodies and speckles. J Med Genet 2004;41:e46.

30 Grewal PK, Carim Todd L, van der Maarel S, Frants RR, Hewitt JE. FRG1, a gene in the FSH muscular dystrophy region on human chromosome $4 \mathrm{q} 35$, is highly conserved in vertebrates and invertebrates. Gene 1998:216:13-9.

31 Van Deutekom JCT, Lemmers RJLF, Grewal PK, van Geel M, Romberg S, Dauwerse HG, Wright TJ, Padberg GW, Hofker MH, Hewitt JE, Frants RR. Identification of the first gene (FRG1) from the FSHD region on human chromosome 4q35. Hum Mol Genet 1996;5(5):581-90.

32 Van Geel M, Heather U, Lyle R, Hewitt JE, Frants RR, de Jong PJ. The FSHD region on human chromosome $4 \mathrm{q} 35$ contains potential coding regions among pseudogenes and a high density of repeat elements. Genomics 1999;61(1):55-65.

33 Shoubridge EA, Johns T, Boulet L. Use of myoblast cultures to study mitochondrial myopathies. Methods Enzymol 1996;264:465-75.

34 Murry CE, Kay MA, Bartosek T, Hauschka SD, Schwartz SM. Muscle differentiation during repair of myocardial necrosis in rats via gene transfer with MyoD. J Clin Invest 1996;98(10):2209-17.

35 Roest PA, Bakker E, Fallaux FJ, Verellen-Dumoulin C, Murry CE, den Dunnen JT. New possibilities for prenatal diagnosis of muscular dystrophies: forced myogenesis with an adenoviral MyoD-vector. Lancet 1999;353(9154):727-8

36 Georgiev O, Bourquin JP, Gstaiger M, Knoepfel L, Schaffner W, Hovens C. Two versatile eukaryotic vectors permitting epitope tagging, radiolabelling and nuclear localisation of expressed proteins. Gene 1996;168(2):165-7

37 Cuppen E, Gerrits H, Pepers B, Wieringa B, Hendriks W. PDZ motifs in PTP-BL and RIL bind to internal protein segments in the LIM domain protein RIL. Mol Biol Cell 1998;9(3):671-83.
38 Langer PR, Waldrop AA, Ward DC. Enzymatic synthesis of biotin labelled polynucleotides: novel nucleic acid affinity probes. Proc Natl Acad Sci U S A 1981;78:6633-7

39 Dauwerse JG, Jumelet EA, Wessels JW, Saris JJ, Hagemeijer A Beverstock GC, van Ommen GJ, Breuning MH. Extensive cross-homology between the long and the short arm of chromosome 16 may explain leukemic inversions and translocations. Blood 1992;79(5):1299-304.

40 Gould SJ, Keller GA, Hosken N, Wilkinson J, Subramani S. A conserved tripeptide sorts proteins to peroxisomes. J Cell Biol 1989;108(5):1657-64.

41 Swinkels BW, Gould SJ, Subramani S. Targeting efficiencies of various permutations of the consensus $C$-terminal tripeptide peroxisomal targeting signal. FEBS Lett 1992;305(2):133-6.

42 Van Geel M, Eichler EE, Beck AF, Shan Z, Haaf T, van der Maarel SM, Frants RR, de Jong PJ. A cascade of complex subtelomeric duplications during the evolution of the hominoid and old world monkey genomes. Am J Hum Genet 2002;70(1):269-78.

43 Mefford HC, Trask BJ. The complex structure and dynamic evolution of human subtelomeres. Nat Rev Genet 2002;3(2):91-102.

44 Winokur ST, Barrett K, Martin JH, Forrester JR, Simon M, Tawil R, Chung SA, Masny PS, Figlewicz DA. Facioscapulohumeral muscular dystrophy (FSHD) myoblasts demonstrate increased susceptibility to oxidative stress. Neuromuscul Disord 2003;13(4):322-33.

45 Figlewicz DA, Barrett K, Leskovar AH, Forrester JR, Sowden JE, Tawil R. FSHD myoblasts: in vitro studies. In: Upadhyaya M, Cooper DN, eds. Facioscapulohumeral muscular dystrophy: clinical medicine and molecular cell biology. Oxon, UK: Garland Science/BIOS scientific publishers, 2004:235-51.

46 Hettema EH, Distel B, Tabak HF. Import of proteins into peroxisomes. Biochim Biophys Acta 1999;1451(1):17-34.

47 Trask BJ, Friedman C, Martin-Gallardo A, Rowen L, Akinbami C, Blankenship J, Collins C, Giorgi D, ladonato S, Johnson F, Kuo WL, Massa H, Morrish T, Naylor S, Nguyen OT, Rouquier S, Smith T, Wong DJ, Youngblom J, van den Engh G. Members of the olfactory receptor gene family are contained in large blocks of DNA duplicated polymorphically near the ends of human chromosomes. Hum Mol Genet 1998;7(1):13-26.

48 Weintraub H, Tapscott SJ, Davis RL, Thayer MJ, Adam MA, Lassar AB Miller AD. Activation of muscle-specific genes in pigment, nerve, fat, liver, and fibroblast cell lines by forced expression of MyoD. Proc Natl Acad Sci U S A 1989;86(14):5434-8.

49 Gerber AN, Klesert TR, Bergstrom DA, Tapscott SJ. Two domains of MyoD mediate transcriptional activation of genes in repressive chromatin: a mechanism for lineage determination in myogenesis. Genes Dev 1997;1 1(4):436-50.

50 Jiang G, Yang F, van Overveld PG, Vedanarayanan V, van der MS, Ehrlich M. Testing the position-effect variegation hypothesis for facioscapulohumeral muscular dystrophy by analysis of histone modification and gene expression in subtelomeric 4q. Hum Mol Genet 2003;12(22):2909-21.

51 Pirrotta V. Transvection and chromosomal trans-interaction effects. Biochim Biophys Acta 1999;1424(1):1-8.

52 Van Geel M, Dickson MC, Beck AF, Bolland DJ, Frants RR, van der Maarel SM, de Jong PJ, Hewitt JE. Genomic analysis of human chromosome 10q and $4 q$ telomeres suggests a common origin. Genomics 2002;79(2):210-7.

53 Lemmers RJ, Osborn M, Haaf T, Rogers M, Frants RR, Padberg GW, Cooper DN, van der Maarel SM, Upadhyaya M. D4F104S1 deletion in facioscapulohumeral muscular dystrophy: phenotype, size, and detection. Neurology 2003:61(2):178-83. 